\title{
Assessment, Monitoring, and Awareness of Garment Workers Regarding the Prevalence of Tuberculosis in Savar, Dhaka
}

\author{
Syed Abdullah-Al-Nahid ${ }^{1 *}$, Taslima Haque ${ }^{2}$, Md. Shoykot Jahan ${ }^{3}$, Ashrafi Akter Jahan ${ }^{4}$, Mohammad \\ Shah Alam ${ }^{5}$, K. M. Shakib ${ }^{6}$, and Ropak Chandra Roy ${ }^{6}$
}

${ }^{1}$ Dept. of Physiology, Gonoshastaya Samaj Vittik Medical \& College Hospital, Bangladesh; ${ }^{2} \mathrm{CMH}$ Dhaka, AMC, Bangladesh Army; ${ }^{3}$ Dept. of Biochemistry and Molecular Biology, Gono Bishwabidyalay, Bangladesh; ${ }^{4}$ Dept. of Anatomy, Gonoshastaya Samaj Vittik Medical \& College Hospital, Bangladesh; ${ }^{5}$ Dept. of Microbiology, Gono Bishwabidyalay, Bangladesh; and ${ }^{6}$ Dept. of Physiotherapy, Gono Bishwabidyalay, Bangladesh

*Correspondence: $\underline{\text { dralnahid.edu@gmail.com }}$

\begin{abstract}
The study was conducted to assess the awareness regarding Tuberculosis (TB) among the garment workers in Savar, Dhaka. Data were collected by face to face interview using a semi-structured questionnaire. A total of 110 garment workers were interviewed, among them, 51.8\% were male and rests of $48.2 \%$ were female. Maximum 30.9\% respondent's age was between $20-22$ years and $28.2 \%$ respondent's ages were more than 28 years. $58.2 \%$ of respondents had secondary education, $22.7 \%$ of respondents had primary education and $14.5 \%$ respondents had HSC and above education. Out of 110 respondents, $60.0 \%$ were lived in a nuclear family, $39.1 \%$ were lived in a joint family, and $34.5 \%$ were at own house, $3.6 \%$ were at slum and $57.3 \%$ were at the colony. The majority had heard about TB (72.7\%) by listening to Television, Radio, Newspaper, and $27.3 \%$ were family member, office, doctors or hospitals. only $25.5 \%$ perceived it to be an infectious disease, $(30.0 \%)$ were did not perceive and highest number $44.5 \%$ were didn't know. The correct mode of transmission i.e. airborne (coughing/sneezing) was known to $66.7 \%$ study subjects. The majority (62.4\%) knew cough as a symptom. Maximum (71.8\%) respondents thought TB to be a preventable disease, among them majority $(52.0 \%)$ were of the opinion to prevent the TB by a cover on the mouth at coughing, $8.1 \%$ were said BCG (Bacillus Calmette-Guérin) vaccination and $35.8 \%$ was no smoking. Most of the respondent's (96.4\%) said TB is a treatable disease, among them, $75.5 \%$ said by Anti TB antibiotics. $62.7 \%$ of respondents knew TB is a completely curable disease. This study shows (74.5\%) garments workers have poor awareness and $(25.5 \%)$ have good awareness.
\end{abstract}

Keywords: Awareness, Tuberculosis, Garment Workers, Mycobacterium, Assessment, and respondents

\section{INTRODUCTION}

Tuberculosis (TB) is a potentially fatal contagious disease that can affect almost any part of the body but is mainly an infection of the lungs. It is caused by a bacterial microorganism, the tubercle Bacillus or Mycobacterium tuberculosis. Although TB can be treated, cured, and can be prevented if persons at risk take certain drugs, scientists have never come close to wiping it out, and few diseases have caused so much distressing illness for centuries and claimed so many lives (Beers Mark \& Robert Berkow, 2004). TB is caused due to infection with the $M$. tuberculosis, but everyone, who gets contaminated with the germ, does not get the disease (Kim et al., 2002). It is feasible to engage factories in TB control activities in Bangladesh, and thereby increase case notifications and improve treatment outcomes (Zafar Ullah et al., 2012). Most of the time, the immune system can prevent you from becoming sick and only about $10 \%$ of people 
infected with TB go to on to develop TB. The common symptoms of TB include cough for a prolonged duration that is more than three weeks, unexplained or intended weight loss, fatigue, general feeling of tiredness, fever, sweating at night, chills and loss of appetite (Roy et al., 2019). Having these signs and symptoms does not mean that have TB (Ellen et al., 2012). Signs and symptoms of active TB may also vary depending on the organ that is affected. Most of the times, the lungs of the patients are affected. Symptoms of TB of the lungs includes cough for three or more weeks, blood in cough, chest pain or pain while breathing or coughing. TB can also affect organs apart from the lungs. The other organs that are affected by TB include lymph nodes, genitourinary nodes, bone, and joint sites, the lining covering the outside of the Gastrointestinal Tract (GIT). After a steady, the decline in TB prevalence, Thailand has experienced a recent re-emergence in new TB cases and pathologically confirmed TB illustrates the increased incidence in Thailand (Amara Soonthorndha et al., 2004).

Tuberculosis is more common in elderly persons, and have lain dormant for some time in elderly persons may be reactivated and cause illness (Houston et al., 2002). TB also is more common in blacks, who are more likely to live under conditions that promote infection. Alcoholics and intravenous drug abusers are also at increased risk of contracting TB. Until the economic and social factors that influence the spread of tubercular infection are remedied, there is no real possibility of completely eliminating the disease (Fielder et al., 2002). TB spreads by droplet infection. Actual tissue damage is not caused directly by the tubercle Bacillus, but by the reaction of the person's tissues to its presence. Cells attack the bacilli, permit the initial damage to heal, and prevent future disease permanently ( $\mathrm{Su}, \mathrm{W}$. J., 2002). On rare occasions, a previously infected person gets sick again after a later exposure to the tubercle Bacillus (Stauffer et al., 2002). Mycobacteria grow in swimming pools and may cause skin infection. Some of them infect wounds and artificial body parts such as a breast implant or mechanical heart valve (Kim et al., 2002). Unlike many other types of bacteria, Mycobacteria can retain certain dyes even when exposed to acid. This so-called acid-fast property is characteristic of the tubercle Bacillus (Stauffer et al., 2002). Polymerase chain reaction to detect Mycobacterial DNA in patient specimens; nucleic acid probes to identify Mycobacteria in culture; restriction fragment length polymorphism analysis to compare different strains of TB for epidemiological studies; and genetic-based susceptibility testing to identify drug-resistant strains of Mycobacteria (Moua et al., 2002). Male and female TB patients, quantitative survey of male and female TB patients, observations of patient-provider interactions at labs, observations of patient-provider interactions during treatment initiation at the community, and key informant interviews with health providers and the Bangladesh study forms a part of this multi-country study (Fazlul Karim et al., 2003; Sharif et al., 2019). No study among the garment workers of Dhaka city has been carried out as yet regarding the incidence of $\mathrm{TB}$ or other infectious respiratory diseases. This study was conducted in randomly selected 30 garment factories of Dhaka city to ascertain the incidence rate of PT among garments workers (MR Hassant et al., 2005).

In the past, treatment of $\mathrm{TB}$ was primarily supportive. Patients were kept in isolation, encouraged to rest, and fed well. Five drugs are most commonly used today to treat TB: isoniazid (INH, Laniazid, and Nydrazid); rifampin (Rifadin, Rimactane); pyrazinamide (Tebrazid); streptomycin; and ethambutol (Myambutol). Vaccination is one major preventive measure against TB. A vaccine called BCG is made from a weakened Mycobacterium that infects cattle. High-risk groups for whom isoniazid prevention may be justified include close contacts of TB patients, including health care workers, persons with positive PPD results and evidence of old disease on the chest X-ray who have never been treated for TB, people from countries with high rates of TB who have positive PPD results, and persons with a positive PPD reaction who belong to high-risk ethnic groups (Beers Mark \& Robert Berkow, 2004; and Pelletier \& Kenneth, 2002). A 26 year old Bangladeshi male was admitted in the Respiratory wing, Bangabandhu Sheikh Mujib Medical University Hospital, Dhaka in June 2007 with the complaints of multiple painful swelling in the chest. Computerized tomography (CT) scan showed lytic lesions in the anterior part of left $2^{\text {nd }}$ rib and anterolateral aspect of the right $6^{\text {th }}$ rib with associated enhancing lesion having both intraand extra-thoracic components suggestive of chest wall abscesses; no parenchymal lesion or mediastinal lymphadenopathy was noted and FNAC 
of anterior chest wall swelling showed scanty (Mosharraf Hossain et al., 2010)

Background Despite enormous efforts, Bangladesh has one of the highest burdens of TB in the world. Treatment in the private sector is common and popular among TB patients in South-Asian countries, including Bangladesh, even though the quality of diagnosis and treatment of TB patients has been shown to be poor in several such countries. The Bangladesh National Tuberculosis Programme (NTP) has recently shown considerable interest in exploring policy options to address this problem. Over one-third of the global populations are infected with M. tuberculosis (WHO, 2009), and they may turn into active TB cases at any time of their life cycle. In activities related to controlling TB, many healthcare workers come into contact with the disease. The underlying hypothesis of our study was that an appropriate public-private partnership model involving garment factories would significantly reduce the TB burden in this workforce, and presented both the process of developing the partnership model and its impact on TB control activities (Zafar Ullah et al., 2012). The main objectives of the study to assess the present level of awareness and misconceptions of TB among the garments workers in Savar, and to determine the socio-economic status of the respondents, and also to assess the awareness level of the respondents regarding causes prevention of TB.

\section{Research Question:}

What is the level of awareness on Tuberculosis among the garments workers in Savar?

\section{List of Key Variables:}

A. Dependent Variables - Awareness of TB, and Misconception of TB.

B. Independent Variables - Age, Sex, Religion, Educational status, Monthly income, Family members, Housing status, Prevention and control of infection, Treatment of TB, and Causes of TB.

\section{Operational Definition:}

Age: At first the age of the cases was taken in actual full years. Smallest value and largest value were taken and after compilation of data collection, all the cases were grouped in four groups.

\section{Educational Status:}

$>$ Illiterate: received no formal education from any institute.

$>$ Primary education from class I group to class V.

$>$ SSS: Secondary education levels from class VI to class X.

$>$ HSC: passed higher secondary school certification (HSC) examination.

Monthly Income: It is the monthly income of the patient or the total income of the head of the family and as well as the income of the other members. Monthly income was recorded in terms of Taka as stated by the respondents and/or their responsible family members.

\section{Type of Family:}

Nuclear Family: It consists of the married couple and their children while they are still regarded as dependents.

Joint Family: It consists of a number of married couples and their children who live together in the same household and share the same food prepared in the same pot.

Number of the Member in the Family: The number of persons who live in the same house and who have their male prepared in the same pot is constituted the family member.

\section{Type of Housing:}

* Kacha: Mudd wall and floor with Bamboo or Hayshed.

* Sami-Pakka: Brick made a floor with Tin on the roof.

\# Tin made: Muddy floor with Tin made wall and roof.

\$ Pakka: Brick made building.

Limitations of the Study: It was an urban garments workers study. During this study, various types of limitations were faced by which may have influenced the quality of the study. The limitations are: It was conducted on small sample size and the study place was selected purposively due to time constraint and it does not necessarily reflect the situation of the whole country, and study population got 20 to 32 years old. But verities age were not available due to their garments workers. 


\section{METHODOLOGY:}

Study Design and Place: This was a cross-sectional study and areas were selected purposively for collecting the sample. The area was purposively selected in Ashulia, Savar, Dhaka.

Study Period and Population: The study was conducted for a period from January-May 2014, when literature review, questionnaire preparation, data collection, and works related to the dissertation was complete. Garments workers who live and works in different garments in Ashulia, Savar, Dhaka.

Inclusion and Exclusion Criteria: Those who gave consent, and those who willing to the participant and those whose residence is not in Ashulia, Savar. Dhaka.

Sample Size and Sampling Technique: The sample size was 110 , and purposive sampling.

Data Collection Instrument and Technique: Data collection tool was a combination of a semistructured questionnaire and used as data collection. Data was collected from the respondent's face-toface interview by using semi-structured questionnaire.

Data Processing and Analysis: All interviewed questionnaires were checked for completeness and correctness before data entry. Data were checked, cleaned and edited properly before analysis. Data were entered into statistical software SPSS 19 programs.

Ethical Consideration: All ethical issues related to reaching were addressed according to the guideline. Permission was taken from the needed (ASA University, Bangladesh) authority. Prior permission was taken from the Director who belongs to study areas. Informed oral consent was taken before the interview from Hospital staff. Participant's had the right to refuse and withdraw from study any time. Confidently was maintained strictly.

\section{RESULT and FINDINGS:}

Findings of the Study: To assess awareness of garments workers with their disease and misconceptions regarding TB. Total of 110 garments workers was selected purposively according to inclusion, exclusion criteria. Data were collected interviewed with a specific pre-designed and pretested questionnaire and some information was gathered by document review. Collected data were cleaned edited and analyzed with the help of software SPSS windows version 19. The analyzed data have been presented in this chapter through tables and appropriate graphs. The results of the study have been described as follows:

Table 1: Distribution of the respondents by age.

\begin{tabular}{|ccc|}
\hline Age & $\begin{array}{c}\text { Number of } \\
\text { respondents }\end{array}$ & Percent \\
\hline 20-22 years & 34 & 30.9 \\
\hline 23-25 years & 23 & 20.9 \\
\hline 25-28 years & 22 & 20.0 \\
\hline >28 years & 31 & 28.2 \\
\hline Total & $\mathbf{1 1 0}$ & $\mathbf{1 0 0 . 0}$ \\
\hline
\end{tabular}

Table 1 shows the age distribution of the garments workers, out of 110 respondents, among them 30.9 $\%$ were in 20-22 years age group, followed by 20.9 $\%$ were in 23-25 years age group, $20.0 \%$ were in $25-28$ years age group and the last number of $28.2 \%$ were $>28$ years age group. Their mean was 26.15 ; $(\mathrm{SD} \pm 4.301)$.

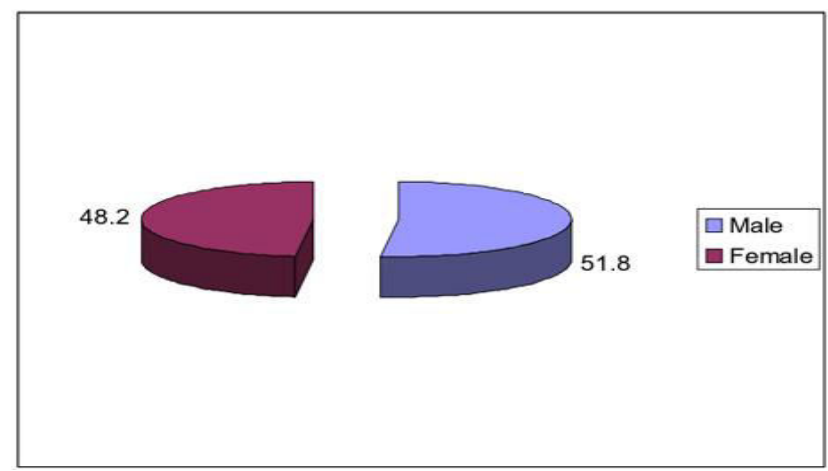

Fig 1: Distribution of the respondents by sex.

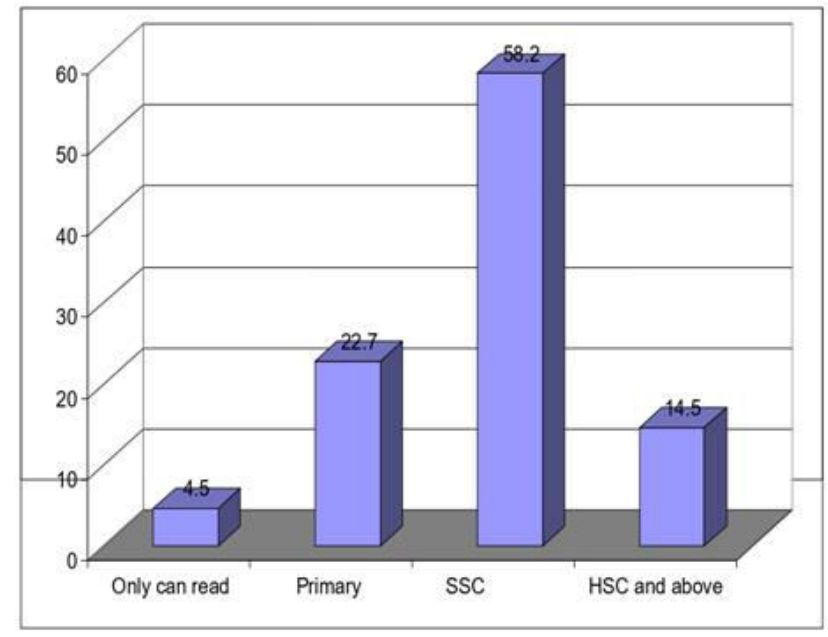

Fig 2: Distribution of the respondents by educational qualification level. 
Fig 1 found that the sex distribution of the garments workers. More than two-fifth (51.8\%) was male and $48.2 \%$ were female garments workers.

The distribution of respondents by their educational status is shown in fig $\mathbf{2}$. Out of 110 respondents, a minimum of $4.5 \%$ were only can read according to 22.7 percent were educated up to primary level, 58.2 $\%$ were SSC level and $14.5 \%$ were HSC and above their educational level.

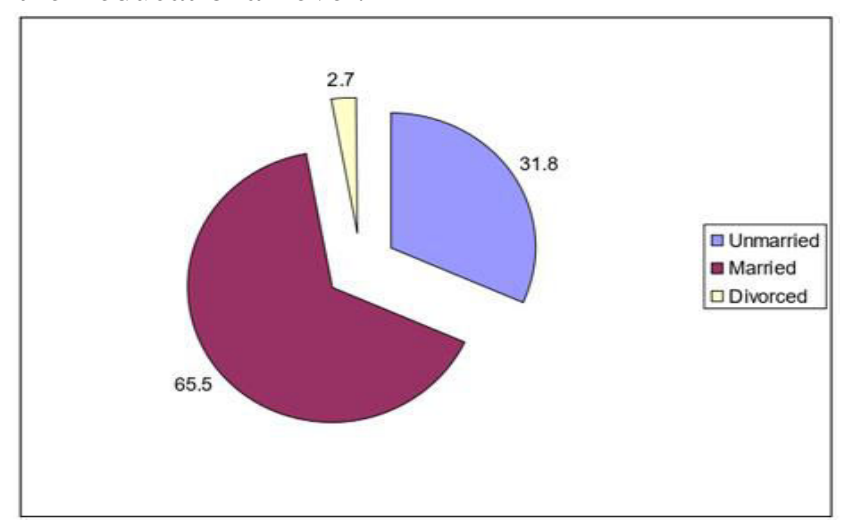

Fig 3: Distribution of the respondents by marital status.

Fig 3 reveals that the majority $65.5 \%$ belonged to married person, 31.8 percent belonged to unmarried and the least number of $2.7 \%$ were divorced.

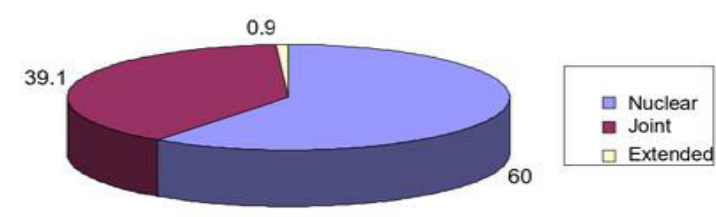

Fig 4: Distribution of the respondents by type of family.

Table 2: Respondents by number of family members.

\begin{tabular}{|ccc|}
\hline $\begin{array}{c}\text { Number of family } \\
\text { member }\end{array}$ & $\begin{array}{c}\text { Number of } \\
\text { respondents }\end{array}$ & Percent \\
\hline 1 member & 17 & 15.5 \\
\hline 2 members & 47 & 42.7 \\
\hline 3 members & 38 & 34.5 \\
\hline$\geq 4$ members & 8 & 7.3 \\
\hline Total & $\mathbf{1 1 0}$ & $\mathbf{1 0 0 . 0}$ \\
\hline
\end{tabular}

Table 2 shows that regarding the number of family member's maximum of $42.7 \%$ were two members followed by $15.5 \%$ was one member, $34.5 \%$ were three members and only $7.3 \%$ were four or more than four members.

Table 3: Respondents by place of residential area.

\begin{tabular}{|ccc|}
\hline Variables & $\begin{array}{c}\text { Number of } \\
\text { respondents }\end{array}$ & Percent \\
\hline Personal house & 38 & 34.5 \\
\hline At slum & 4 & 3.6 \\
\hline At colony & 63 & 57.3 \\
\hline Others & 5 & 4.5 \\
\hline Total & $\mathbf{1 1 0}$ & $\mathbf{1 0 0 . 0}$ \\
\hline
\end{tabular}

Table 3 represents the distribution of the present in life. Among them, $34.5 \%$ were live personal house according to $3.6 \%$ were living at the slum, $57.3 \%$ were living in colony and only $4.5 \%$ were others.

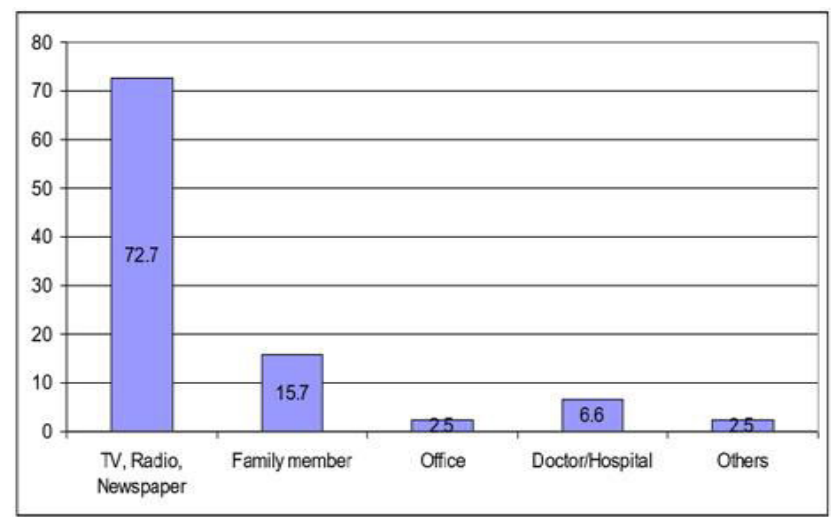

Fig 5: Distribution of the respondents by source of information about TB (Multiple responses).

Fig 4 shows that regarding the type of family maximum $(60.0 \%)$ were lived in a nuclear family, $39.1 \%$ were living in a joint family and the lowest number of $0.9 \%$ was lived in extended family. Fig 6 showed that regarding the source of information about the TB maximum $72.7 \%$ were listening to Television, Radio, Newspaper, $15.7 \%$ were family member, $2.5 \%$ were Office, $6.6 \%$ were Doctor/Hospital and only $2.5 \%$ other sources of information about TB.

Table 4: Respondents by conception about TB.

\begin{tabular}{|ccc|}
\hline $\begin{array}{c}\text { Conception about } \\
\text { tuberculosis }\end{array}$ & $\begin{array}{c}\text { Number of } \\
\text { respondents }\end{array}$ & Percent \\
\hline Yes & 91 & 82.7 \\
\hline No & 19 & 17.3 \\
\hline Total & $\mathbf{1 1 0}$ & $\mathbf{1 0 0 . 0}$ \\
\hline
\end{tabular}

Table 4 found that regarding on TB highest of 82.7 $\%$ had conception and $17.3 \%$ had no conception about TB. 
Table 5: Respondents idea level by causes of TB.

\begin{tabular}{|ccc|}
\hline $\begin{array}{c}\text { Causes of } \\
\text { tuberculosis }\end{array}$ & $\begin{array}{c}\text { Number of } \\
\text { respondents }\end{array}$ & Percent \\
\hline Virus & 19 & 11.1 \\
\hline Bacteria & 7 & 4.1 \\
\hline Dust & 66 & 38.6 \\
\hline Cold & 66 & 38.6 \\
\hline Others & 13 & 7.6 \\
\hline Total & $\mathbf{1 7 1}$ & $\mathbf{1 0 0 . 0}$ \\
\hline
\end{tabular}

Table 5 shows that the highest $38.6 \%$ were same responses regarding causes of $\mathrm{TB}, 11.1 \%$ were told virus and only $7.6 \%$ were told others.

Table 6: Respondents by the history of suffering TB.

\begin{tabular}{|c|c|c|}
\hline $\begin{array}{c}\text { History of previous } \\
\text { suffering of } \\
\text { tuberculosis }\end{array}$ & $\begin{array}{c}\text { Number of } \\
\text { respondents }\end{array}$ & $\begin{array}{c}\text { Percen } \\
\mathbf{t}\end{array}$ \\
\hline Yes & 9 & 8.2 \\
\hline No & 101 & 91.8 \\
\hline Total & $\mathbf{1 1 0}$ & $\mathbf{1 0 0 . 0}$ \\
\hline
\end{tabular}

In regards to the history of the previous suffering of TB, $8.2 \%$ yes and the majority of $91.8 \%$ were no history of previous suffering of TB (Table 6).

Table 7: Respondents by the place affected TB.

\begin{tabular}{|ccc|}
\hline $\begin{array}{c}\text { Affected place of } \\
\text { tuberculosis }\end{array}$ & $\begin{array}{c}\text { Number of } \\
\text { respondents }\end{array}$ & Percent \\
\hline Village & 6 & 66.7 \\
\hline Garments & 3 & 33.3 \\
\hline Total & 9 & $\mathbf{1 0 0 . 0}$ \\
\hline
\end{tabular}

Table 8: Respondents by duration of suffering TB.

\begin{tabular}{|ccc|}
\hline $\begin{array}{c}\text { Duration of } \\
\text { suffering }\end{array}$ & $\begin{array}{c}\text { Number of } \\
\text { respondents }\end{array}$ & Valid Percent \\
\hline One year & 2 & 22.2 \\
\hline Two years & 4 & 44.4 \\
\hline Three years & 2 & 22.2 \\
\hline Four years & 1 & 11.1 \\
\hline Total & $\mathbf{9}$ & $\mathbf{1 0 0 . 0}$ \\
\hline
\end{tabular}

Among the affected from a place of TB shows in Table 7 and More than two third (66.7\%) were affected by the village and $33.3 \%$ were affected garments sectors. Based on sputum examination, demonstrated that, $0.87 \%$ of adult population, which was $0.46 \%$ of the total population, was suffering from infectious pulmonary TB. Table 8 reveals that the maximum $44.4 \%$ garments workers said their affected TB before from two years, $22.2 \%$ were before one \& two years and only $11.1 \%$ were said four years and the most common forms of knowledge on symptoms of TB the study population.

Table 9: Respondents by knowledge on sign and symptoms of TB.

\begin{tabular}{|ccc|}
\hline $\begin{array}{c}\text { Knowledge on } \\
\text { symptoms of TB }\end{array}$ & Frequency & Percent \\
\hline $\begin{array}{c}\text { Fever } \\
\text { More than two weeks } \\
\text { cough }\end{array}$ & 9 & 6.8 \\
\hline Diarrhea with vomiting & 3 & 62.4 \\
\hline Weight loss & 9 & 2.3 \\
\hline $\begin{array}{c}\text { Chest pain with } \\
\text { Asphyxia }\end{array}$ & 20 & 15.8 \\
\hline Pain of nerve & 1 & 0.8 \\
\hline Cough with bleeding & 5 & 3.8 \\
\hline Others & 3 & 2.3 \\
\hline Total & $\mathbf{1 3 3}$ & $\mathbf{1 0 0 . 0}$ \\
\hline
\end{tabular}

The most common forms of knowledge on symptoms of TB the study population. Highest (62.4\%) were said on symptoms of TB more than two weeks cough, $15.0 \%$ were said chest pain with asphyxia of symptoms of TB. A considerable percentage was found to weight loss i.e. 6.8\% (Table 9). The four most commonly recognized symptoms of TB were thought to be cough (83.5\%), fever $(54.7 \%)$, chest pain $(24.7 \%)$ and bloody sputum $(24.7 \%)$. Twenty-eight $(17 \%)$ responders thought that TB occurred only once in a life-time and did not recur for a second time after treatment. Thirty-one (19\%) patients believed that the total duration of treatment was less than 6 months; while $31(18 \%)$ were of the view that treatment should be stopped following control of symptoms (Rizvi et al., 2006).

From Table 10 shows that total of 110 garments workers interviewed which sex and age affected on TB. Maximum respondents $79.1 \%$ were told male, $7.3 \%$ were female and $13.6 \%$ were child responses.

Table 10: Respondents by the sex \& age who are more affected.

\begin{tabular}{|ccc|}
\hline Person affected & $\begin{array}{c}\text { Number of } \\
\text { respondents }\end{array}$ & Percent \\
\hline Male & 87 & 79.1 \\
\hline Female & 8 & 7.3 \\
\hline Child & 15 & 13.6 \\
\hline Total & $\mathbf{1 1 0}$ & $\mathbf{1 0 0 . 0}$ \\
\hline
\end{tabular}




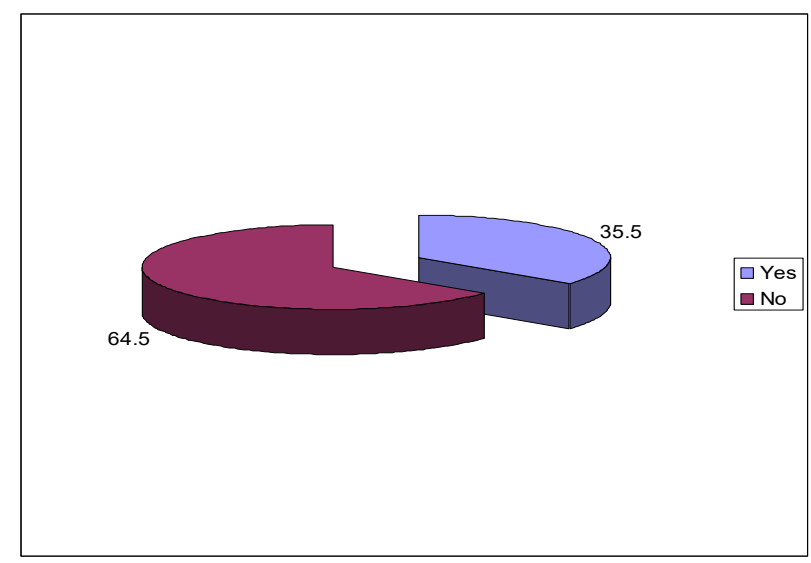

Fig 6: Distribution of the respondents by smoking habit.

Fig 6 found that the majority of $64.5 \%$ were no smoking habit and only $35.5 \%$ were smoking habit.

Table 11: Knowledge of respondents by duration of the smoking habit.

\begin{tabular}{|ccc|}
\hline $\begin{array}{c}\text { Duration of } \\
\text { smoking habit }\end{array}$ & $\begin{array}{c}\text { Number o } \\
\text { respondents }\end{array}$ & Percent \\
\hline 1 year & 12 & 30.8 \\
\hline 2 years & 11 & 28.2 \\
\hline 3 years & 13 & 33.3 \\
\hline 4 years & 3 & 7.7 \\
\hline Total & $\mathbf{3 9}$ & $\mathbf{1 0 0 . 0}$ \\
\hline
\end{tabular}

Table 12: Respondents idea by the transmission of TB pathogens.

\begin{tabular}{|ccc|}
\hline Variables & $\begin{array}{c}\text { Number of } \\
\text { respondents }\end{array}$ & Percent \\
\hline $\begin{array}{c}\text { Through the air by } \\
\text { droplet of TB patients }\end{array}$ & 80 & 66.7 \\
\hline $\begin{array}{c}\text { To eating with TB } \\
\text { patient }\end{array}$ & 13 & 10.8 \\
\hline With intercourse & 3 & 2.5 \\
\hline With touch & 5 & 4.2 \\
\hline Don't know & 19 & 15.8 \\
\hline Total & $\mathbf{1 2 0}$ & $\mathbf{1 0 0 . 0}$ \\
\hline
\end{tabular}

Table 11 states that the distribution of duration of the smoking habit. Among them one third (30.8\%) were the duration of one year according to $28.2 \%$ were two years, $33.3 \%$ were three years and only the least number $7.7 \%$ was four years.

Table 12 found that distribution of the garments workers respondents, maximum respondents were multiple responses of transmission of TB. Among the majority of more than two third $(66.7 \%)$ were opinion source through the air by a droplet of TB patients germ, according to $10.8 \%$ were opinion to eating with TB patient, $2.5 \%$ were opinion with intercourse with TB patients and $4.2 \%$ with touch, $15.8 \%$ were don't know about transmission of TB.

Table 13: Idea of the Respondents by $\mathrm{TB}$ is an infectious disease.

\begin{tabular}{|ccc|}
\hline $\begin{array}{c}\text { TB is a infectious } \\
\text { disease }\end{array}$ & $\begin{array}{c}\text { Number of } \\
\text { respondents }\end{array}$ & Percent \\
\hline Yes & 28 & 25.5 \\
\hline No & 33 & 30.0 \\
\hline Don't know & 49 & 44.5 \\
\hline Total & $\mathbf{1 1 0}$ & $\mathbf{1 0 0 . 0}$ \\
\hline
\end{tabular}

Table 13 shows that the $25.5 \%$ were told TB is an infectious disease, (30.0\%) were TB is not an infectious disease and highest number of $44.5 \%$ was don't know about TB disease.

Table 14: Respondents idea by $\mathrm{TB}$ is a preventable disease.

\begin{tabular}{|ccc|}
\hline $\begin{array}{c}\text { TB is a preventable } \\
\text { disease }\end{array}$ & $\begin{array}{c}\text { Number of } \\
\text { respondents }\end{array}$ & Percent \\
\hline Yes & 79 & 71.8 \\
\hline No & 11 & 10.0 \\
\hline Don't know & 20 & 18.2 \\
\hline Total & $\mathbf{1 1 0}$ & $\mathbf{1 0 0 . 0}$ \\
\hline
\end{tabular}

Table 15: Respondents by methods of TB prevention.

\begin{tabular}{|ccc|}
\hline $\begin{array}{c}\text { Methods of TB } \\
\text { prevention }\end{array}$ & $\begin{array}{c}\text { Number of } \\
\text { respondents }\end{array}$ & Percent \\
\hline BCG vaccination & 10 & 8.1 \\
\hline $\begin{array}{c}\text { Cover on mouth at } \\
\text { cough }\end{array}$ & 64 & 52.0 \\
\hline No smoking & 44 & 35.8 \\
\hline $\begin{array}{c}\text { Increase of personal } \\
\text { cleanliness }\end{array}$ & 1 & 0.8 \\
\hline Don't know & 4 & 3.3 \\
\hline Total & $\mathbf{1 2 3}$ & $\mathbf{1 0 0 . 0 \%}$ \\
\hline
\end{tabular}

Table 14 found that the majority of $71.8 \%$ garments workers were response $\mathrm{TB}$ is a preventable disease but $10.0 \%$ were not a preventable diseases and 18.2 $\%$ were don't know. Table 15 reveals that the distribution of the garments workers respondents, maximum respondents were multiple responses by the methods of TB prevent. Among them majority of $52.0 \%$ were opinion cover on the mouth at cough, followed by $8.1 \%$ were said BCG vaccination, 35.8 $\%$ were no smoking and $3.3 \%$ were don't know how to prevent it. 
Table 16: Respondents by TB is a treatable disease.

\begin{tabular}{|ccc|}
\hline $\begin{array}{c}\text { TB is a treatable } \\
\text { disease }\end{array}$ & $\begin{array}{c}\text { Number of } \\
\text { respondents }\end{array}$ & Percent \\
\hline Yes & 106 & 96.4 \\
\hline No & 1 & 0.9 \\
\hline Don't know & 3 & 2.7 \\
\hline Total & $\mathbf{1 1 0}$ & $\mathbf{1 0 0 . 0}$ \\
\hline
\end{tabular}

As revealed from Table 16, maximum $96.4 \%$ garment worker said it has treatment but $3.6 \%$ there are not idea treatment TB diseases.

Table 17: Respondents by duration of TB treatment of the affected persons.

\begin{tabular}{|ccc|}
\hline $\begin{array}{c}\text { Duration of } \\
\text { TB treatment }\end{array}$ & $\begin{array}{c}\text { Number of } \\
\text { respondents }\end{array}$ & Percent \\
\hline 1 months & 9 & 8.2 \\
\hline 2 months & 17 & 15.5 \\
\hline 3 months & 20 & 18.2 \\
\hline 6 months & 56 & 50.9 \\
\hline 1 years & 8 & 7.3 \\
\hline Total & $\mathbf{1 1 0}$ & $\mathbf{1 0 0 . 0}$ \\
\hline
\end{tabular}

Table 17 reveals that the duration of treatment, more than fifty $(50.9 \%)$ were said six months, according to $8.2 \%$ were one month, $15.5 \%$ were two months, $18.2 \%$ were three months and the least $7.3 \%$ were one year's duration of treatment of TB disease.

Table 18 represents that the highest number of 74.5 $\%$ were said to cure the TB disease but $21.5 \%$ don't know or no idea about the cure for TB diseases.

Table 19 found that the highest number of $75.5 \%$ were possible way to cure TB disease followed by
$14.5 \%$ were TB can't be cured only manage and 6.4 percent were normal antibiotic.

Table 18: Respondents by TB is a curable disease.

\begin{tabular}{|ccc|}
\hline Cure of TB & $\begin{array}{c}\text { Number of } \\
\text { respondents }\end{array}$ & Percent \\
\hline Yes & 82 & 74.5 \\
\hline No & 6 & 5.5 \\
\hline Don't know & 22 & 20.0 \\
\hline Total & $\mathbf{1 1 0}$ & $\mathbf{1 0 0 . 0}$ \\
\hline
\end{tabular}

Table 19: Respondents by possible ways of cure TB.

\begin{tabular}{|ccc|}
\hline $\begin{array}{c}\text { Possible way to cure } \\
\text { from TB }\end{array}$ & $\begin{array}{c}\text { Number of } \\
\text { respondents }\end{array}$ & $\begin{array}{c}\text { Percen } \\
\mathbf{t}\end{array}$ \\
\hline Normal antibiotic & 7 & 6.4 \\
\hline $\begin{array}{c}\text { TB can't be cured only } \\
\text { manage }\end{array}$ & 16 & 14.5 \\
\hline $\begin{array}{c}\text { Total rest without } \\
\text { medicine }\end{array}$ & 1 & 0.9 \\
\hline $\begin{array}{c}\text { Anti-TB } \\
\text { antibiotics/treatment }\end{array}$ & 83 & 75.5 \\
\hline $\begin{array}{c}\text { Vashoz/Herbal } \\
\text { medicine }\end{array}$ & 3 & 2.7 \\
\hline Total & $\mathbf{1 1 0}$ & $\mathbf{1 0 0 . 0}$ \\
\hline
\end{tabular}

Table 20: Respondents by TB is completely curable.

\begin{tabular}{|ccc|}
\hline $\begin{array}{l}\text { TB is a complete } \\
\text { curable disease }\end{array}$ & $\begin{array}{c}\text { Number of } \\
\text { respondents }\end{array}$ & Percent \\
\hline Yes & 69 & 62.7 \\
\hline No & 6 & 5.5 \\
\hline Don't know & 35 & 31.8 \\
\hline Total & $\mathbf{1 1 0}$ & $\mathbf{1 0 0 . 0}$ \\
\hline
\end{tabular}

Table 20 represents that the more than $62.7 \%$ were said TB is a completely curable disease but $5.5 \%$ said TB is not a complete curable disease and $31.8 \%$ were don't no idea the complete cure of TB diseases.

Table 21: Relationship between the age of the respondents and level of awareness on TB.

\begin{tabular}{|c|c|c|c|c|c|c|c|}
\hline \multirow[t]{3}{*}{ Age group } & \multicolumn{4}{|c|}{ Level of Awareness on Tuberculosis } & \multirow[t]{3}{*}{ Total $(\%)$} & \multirow[t]{3}{*}{$x^{2}$} & \multirow[t]{3}{*}{ P-value } \\
\hline & \multicolumn{2}{|c|}{ Poor Awareness } & \multicolumn{2}{|c|}{ Good Awareness } & & & \\
\hline & No & $\%$ & No & $\%$ & & & \\
\hline$<25$ years & 42 & 73.7 & 15 & 26.3 & $57(100.0)$ & & \\
\hline$\geq 25$ years & 40 & 75.5 & 13 & 24.5 & $53(100.0)$ & 0.046 & 0.83 \\
\hline Total & 82 & 74.5 & 28 & 25.5 & $110(100.0)$ & & \\
\hline
\end{tabular}

Table 21 reveals that, the relationship between the age of respondents and the level of awareness of TB was compared by Pearson's Chi-square test in which the ' $\mathrm{P}$ ' value is 0.83 which is higher than the expected value that is 0.05 . So the relationship is not statistically significant.
Table 22 reveals that, the relationship between the education of garments workers and the level of awareness on TB was compared by Pearson's Chisquare test in which the ' $\mathrm{P}$ ' value is 0.05 which is lower than the expected value that is 0.05 . So the relationship is statistically significant. 
Table 22: Relationship between the educational level of the respondents and level of awareness on TB.

\begin{tabular}{|c|c|c|c|c|c|c|c|}
\hline \multirow[t]{3}{*}{ Education } & \multicolumn{4}{|c|}{ Level of Awareness on Tuberculosis } & \multirow[t]{3}{*}{ Total (\%) } & \multirow[t]{3}{*}{$\chi^{2}$} & \multirow[t]{3}{*}{ P-value } \\
\hline & \multicolumn{2}{|c|}{ Poor Awareness } & \multicolumn{2}{|c|}{ Good Awareness } & & & \\
\hline & No & $\%$ & No & $\%$ & & & \\
\hline $\begin{array}{l}\text { Lower } \\
\text { educated }\end{array}$ & 73 & 77.7 & 21 & 22.3 & $94(100.0)$ & & \\
\hline $\begin{array}{l}\text { Higher } \\
\text { educated }\end{array}$ & 9 & 56.2 & 7 & 43.8 & $16(100.0)$ & 0.3 .32 & 0.05 \\
\hline Total & 82 & 74.5 & 28 & 25.5 & $110(100.0)$ & & \\
\hline
\end{tabular}

\section{DISCUSSION:}

This study was conducted to Dhaka based selected awareness of garment workers regarding TB in Savar. The analyzed data have been presented in this chapter through tables and appropriate graphs. The results of the study have been described as TB is a major public health problem in Bangladesh as well as in the whole world. The problem is much greater in poor \& developing countries adverse influence on productivity as its prevalence is seen high. Our study people, their taking of awareness about TB were identified. Bangladesh ranked the $6^{\text {th }}$ highest for the burden of TB among 22 high-burden countries in 2007, with 353,000 new cases, 70,000 deaths, and an incidence of 223/100,000 people per year (WHO report 2009).

In this study was conducted on 110 garments workers. The respondents the age of 17 to 37 years and 30.9 percent were in 20-22 years age group, followed by 20.9 percent were in 23-25 years age group, 20.0 percent were in 25-28 years age group and the last number of 28.2 percent were $>28$ years age group. Their mean was 26.15; (SD \pm 4.301$)$. In this study $51.8 \%$ were male and 48.2 percent were female garments workers. Another study, 53\% were male and $46.4 \%$ were female in the study of Portero NJ (2002) $73.6 \%$ males and $26.4 \%$ females. Forty seven $(27.6 \%)$ had not heard of TB before they were diagnosed themselves and $16(9.4 \%)$ thought that it was a rare disease in Pakistan. Eleven (7\%) did not consider $\mathrm{TB}$ as an infectious disease. Inhaled droplets were recognized as the common source of infection but eating contaminated food (47.6\%), use of blood products $(32.9 \%)$ and inheritance $(27 \%)$ were also considered important modes of transmission. Lung was considered as the only organ affected by TB by 39 (23\%) patients and 96 (57\%) thought that stress and emotional trauma could lead to TB (Rizvi et al., 2006). So the relationship is statistically significant and various surveys have been conducted to understand the knowledge, attitudes, and practices regarding TB. One survey in India reported that most (93\%) people had heard of TB but only $20.5 \%$ of the people demonstrated sufficient knowledge of TB (Devey, 2000, and Shetty et al., 2004).

\section{CONCLUSION:}

The study of awareness of garment workers regarding TB in Ashulia, Savar, and Dhaka, Bangladesh are relatively higher than among the general population. The level of education, monthly income increases the chance of awareness of TB in the garment workers. This study was $51.8 \%$ were male workers and $48.2 \%$ were female workers. Most of the workers were between 20 to 37 years of age, $95.5 \%$ of workers were literate, of them about $72.7 \%$ of workers were educated up to primary or secondary school level. Majority of the garment's workers $(48.20 \%)$ had monthly family income in the group of Taka 10000-15000. Maximum (60.0\%) garments workers lived in the nuclear family, $39.1 \%$ belonged to joint family, $72.7 \%$ respondents heard the information about TB by listening of Radio, seeing of Television, and reading of Newspaper and $27.3 \%$ were from a family member, office, doctor/hospitals. Majority of $(71.8 \%)$ garments workers were response TB is a preventable disease but only $8.1 \%$ were said by BCG vaccination; 21.5 $\%$ didn't know the idea of how TB diseases will be cure, and $31.8 \%$ were didn't know TB is a completely curable disease. Total of 110 respondents among them maximum $(82.7 \%)$ of the respondents had knowledge about tuberculosis but the least number $(17.3 \%)$ were no knowledge about TB. The study was done in a selected small urban area among the garments workers of particularly low socio- 
economic condition. If it were done in a wide range in urban selected areas then it would be more fruitful. Further research is warranted to improve diagnostics, develop new drugs and vaccines, simple and effective regimen for simultaneous treatment of $\mathrm{TB}$, ways to improve program effectiveness, and a better understanding of the relationship between TB and chronic diseases, e.g. TB and smoking, and identify social and behavioral factors which limit the detection of cases.

\section{ACKNOWLEDGEMENT:}

Many thanks to the co-authors supported with proper assistance and help for data analysis to conduct successful research work.

\section{CONFLICTS OF INTEREST:}

The author (s) declared no potential conflicts of the interest with respect to the present research work.

\section{REFERENCES:}

1. Amara Soonthorndhada, Yupin Vorasiriamon, Sally Theobald, Helen Smith (2004). Community Perceptions and Experiences of TB in Kanchanaburi, Thailand: A Gender Equity Analysis, Institute for Population and Social Research, Mahidol University Publication No: 287; ISBN: 974-9716-18-3, 1-69.

2. Beers Mark H., and Robert Berkow (2004). "Infectious Diseases Caused by Mycobacteria." The Merck Manual of Diagnosis and Therapy. Whitehouse Station, NJ: Merck Research Laboratories.

3. Devey J. (2000). Report on knowledge, attitude, and practices (KAP) survey regarding TB conducted in northern Bihar: report on an independent study conducted during an HNGR internship with Champak and Chetna Community Health and Development Projects, Duncan Hospital Bihar, India, May to November. 23.

4. Ellen M. H. Mitchell, Adrienne Shapiro, Jonathan Golub, Kathrina Kranzer, Ana Victoria, Portocarrero, Camilo Antillón Najlis, Jintana Ngamvithayapong-Yanai, Knut Lönnroth (2012). Acceptability of TB Screening among At-Risk and Vulnerable Groups: A Systematic Qualitative/ Quantitative, Literature Metasynthesis, 1-67.
5. Fazlul Karim, Insana Begum, Akramul Islam, AMR Chowdhury (2003). "Gender barriers to Tuberculosis control: Fade-out or in? This investigation received financial support from UNDP/World Bank/WHO Special Program for, Research and Training in Tropical Diseases (TDR)." BRAC Research and Evaluation Division, 1-29.

6. Fielder, J. F., C. P. Chaulk, and Dalvi M. (2005). "A High TB Case-Fatality Rate in a Setting of Effective Tuberculosis Control: Implications for Acceptable Treatment Success Rates." Inter. J. of Tuberculosis and Lung Dis., 6: 1114-1117.

7. Houston, H. R., N. Harada, and T. Makinodan. (2002). "Development of a Culturally Sensitive Educational Intervention Program to Reduce the High Incidence of TB Among Foreign-Born Vietnamese." Ethnic Health, 7: 255-265.

8. Kim, D. Y., Ridzon R., Giles B., and Mireles T. (2002) "Pseudo-Outbreak of Tuberculosis in Poultry Plant Workers, Sussex County, Delaware." J. of Occupational and Environmental Medicine, 44: 1169-1172.

9. Mosharraf Hossain, Abul Kalam Azzad, Samprity Islam, Mohibul Aziz (2010). Multiple chest wall TB abscesses Respiratory Wing, Department of Medicine and Surgery, Bangabandhu Sheikh Mujib Medical University, Dhaka, Bangladesh. 60 (7), 1-3.

10. Moua, M., Guerra F. A., Moore J. D., and Valdiserri R. O. (2002). "Immigrant Health: Legal Tools/Legal Barriers." Journal of Law and Medical Ethics, 30 (3): 189-196.

11. MR Hassant, KS Bennoort, MF Rahman, AM Mahmudt, MA Hossain, GMM Habib, MH Kabir, and AKM Shamsul Huq. (2005). Incidence of Pulmonary Tuberculosis in Garments, Workers of Dhaka City, Bangladesh; Bangladesh Med. Res. Counc. Bull., 31 (1), 7-14.

12. Pelletier, Kenneth R., MD. (2002). The Best Alternative Medicine, Part II, "CAM Therapies for Specific Conditions: Tuberculosis." New York: Simon \& Schuster.

13. Portero NJ, Rubio YM, Pasicatan MA (2002). Socio-economic determinants of knowledge and attitudes about Tuberculosis 
among the general population of Metro Manila, Philippines. Int. J. Tuberc. Lung Dis. 6 (4): 301-6.

14. Rizvi N, Andreasen A, Chow J, Muzaffar R, ur-Rehman H, Siddiqui N, Hasan S, and Bokhari A. (2009). HIV and other sexually transmitted infections among men, transgender, and women selling sex in two cities in Pakistan: a cross-sectional prevalence survey. Sex Transm Infect. 85 (2): 8-16.

15. Roy RC, Sahabuddin M, Debnath SC, Hosaain MJ, Hossain MA, Barman SC, Hasan A, Uddin J, Haque MS, and Saha B. (2019). Nutritional Status of the Adolescent Boys of a Recognized Charitable Orphanage in Dhaka City, Bangladesh. Europ. J. of Med. and Health Sci., 1 (3), 10-18. https://doi.org/10.34104/ejmhs.01018

16. Sharif IH, Tamanna S, Mosaib MG, Tamanna N, Haque MA, Jamal MAHM, and Uddin ME. (2019). Assessment and Biomonitoring of the Effect of Rapeseeds Oil on Wister Rat Organs. Amer. J. of Pure and Appl. Biosci., 1 (4), 20-29. https://doi.org/10.34104/ajpab.019.0192029
17. Shetty N, Shemko M, and Abbas A. (2004). Knowledge, attitudes and practices regarding Tuberculosis among immigrants of Somalian ethnic origin in London: a cross-sectional study. Commun Dis. Public Health. 7: 77-82

18. Stauffer, W. M., D. Kamat, and P. F. Walker. (2002). "Screening of International Immigrants, Refugees, and Adoptees." Primary Care, 29: 879-905.

19. Su, W. J. (2002). "Recent Advances in the Molecular Diagnosis of Tuberculosis." J. of Microbiology, Immunology, and Infection, 35: 209-214.

20. WHO report (2009). Geneva: World Health Organization; 303, (WHO/HTM/TB/2009. 411).

21. Zafar Ullah A.N., Huque R., Husain A., Akter S., Akter H., and Newell J. N. (2012). Tuberculosis in the workplace: developing partnerships with the garment industries in Bangladesh, Int. J. Tuberc. Lung Dis. 16 (12):1637-1642.

http://dx.doi.org/10.5588/ijtld.12.0378

Citation: Nahid SAA, Haque T, Jahan MS, Jahan AA, Alam MS, Shakib KM, and Roy RC (2019). Assessment, Monitoring, and Awareness of Garment Workers Regarding the Prevalence of Tuberculosis in Savar, Dhaka. Europ. J. of Med. and Health Sci., 1 (5), 30-40. https://doi.org/10.34104/ejmhs.03040 